\title{
Peripartal rumen-protected methionine supplementation to higher energy diets elicits positive effects on blood neutrophil gene networks, performance and liver lipid content in dairy cows
}

\author{
Cong Li ${ }^{1}$, Fernanda Batistel ${ }^{2}$, Johan Samir Osorio ${ }^{3}$, James K. Drackley², Daniel Luchini ${ }^{4}$ and Juan J. Loor ${ }^{2^{*}}$
}

\begin{abstract}
Background: Main objectives were to determine to what extent Smartamine M (SM) supplementation to a prepartal higher-energy diet could alter neutrophil (PMN) and liver tissue immunometabolic biomarkers, and whether those responses were comparable to those in cows fed a prepartal lower-energy diet (CON).

Results: Twenty-eight multiparous Holstein cows were fed $C O N\left(N E_{L}=1.24 \mathrm{Mcal} / \mathrm{kg} \mathrm{DM}\right)$ during $\mathrm{d}-50$ to $\mathrm{d}-22$ relative to calving. From $\mathrm{d}-21$ to calving, cows were randomly assigned to a higher-energy diet $\left(\mathrm{OVE}, n=9 ; \mathrm{NE}_{\mathrm{L}}=1.54 \mathrm{Mcal} / \mathrm{kg}\right.$ $\mathrm{DM})$, OVE plus SM (OVE $+\mathrm{SM}, n=10 ; \mathrm{SM}=0.07 \%$ of DM) or remained on CON $(n=9)$. All cows received the same basal lactation diet $\left(N_{L}=1.75 \mathrm{Mcal} / \mathrm{kg} \mathrm{DM}\right)$. Supplementation of SM $(\mathrm{OVE}+\mathrm{SM})$ continued until $30 \mathrm{~d}$ postpartum. Liver biopsies were harvested at $d-10,7$, and 21 relative to parturition. Blood PMN isolated at $-10,3$, and $21 \mathrm{~d}$ relative to calving was used to evaluate gene expression. As expected, OVE increased liver lipid content postpartum; however, cows fed OVE + SM or CON had lower concentrations than OVE. Compared with OVE, cows in CON and OVE + SM had greater DMI postpartum and milk production. Furthermore, cows fed OVE + SM had the greatest milk protein and fat percentage and lowest milk SCC despite having intermediate PMN phagocytic capacity. Adaptations in PMN gene expression in OVE + SM cows associated with the lower SCC were gradual increases from -10 to $21 \mathrm{~d}$ in genes that facilitate migration into inflammatory sites (SELL, ITGAM), enzymes essential for reducing reactive oxygen metabolites (SOD1, SOD2), and a transcription factor(s) required for controlling PMN development (RXRA). The greater expression of TLR4 on d 3, key for activation of innate immunity due to inflammation, in OVE compared with CON cows suggests a more pronounced inflammatory state. Feeding OVE + SM dampened the upregulation of TLR4, despite the fact that these cows had similar expression of the pro-inflammatory genes NFKB1 and TNF as OVE. Cows in CON had lower overall expression of these inflammation-related genes and GSR, which generates reduced glutathione, an important cellular antioxidant.
\end{abstract}

Conclusions: Although CON cows appeared to have a less stressful transition into lactation, SM supplementation was effective in alleviating negative effects of energy-overfeeding. As such, SM was beneficial in terms of production and appeared to boost the response of PMN in a way that improved overall cow health.

Keywords: Blood neutrophil, Gene expression, Methionine

\footnotetext{
* Correspondence: jloor@illinois.edu

${ }^{2}$ Department of Animal Sciences and Division of Nutritional Sciences,

University of Illinois, Urbana, IL 61801, USA

Full list of author information is available at the end of the article
} 


\section{Background}

Cows around calving time experience a depression on immune function partially due to the marked negative energy balance (NEB), which results when cows cannot ingest enough nutrients to support dietary requirements for milk production. During this time, methionine (Met) as one of the first limiting AA in dairy cows may be in limited supply. Research has demonstrated that Met plays a key role in milk protein synthesis, hepatic lipid metabolism, and immune function [1-3].

The decreased immune function during the peripartal period is partly responsible for the high incidence of infections [4, 5]. An effective immune response relies upon the efficient activation of polymorphonuclear neutrophils (PMN) [6]. PMN account for $25 \%$ of leukocytes in bovine peripheral blood of healthy animals [7] and form the first line of cellular defense against invading pathogens [8].

Controlling prepartal energy intake has been associated not only with optimized hepatic lipid metabolism $[9,10]$ but also with a reduced inflammatory response after calving [9]. In contrast, energy-overfed cows often have greater hepatic lipid accumulation [11-13] increasing the risk of metabolic disorders during the peripartal period. Earlier studies have reported that over-feeding energy diets during the close-up period leads to a striking increase in serum NEFA and BHBA postcalving, both of which likely affect the immune response $[14,15]$. We have recently observed that over-feeding energy during the dry period upregulated the expression of genes associated with the proinflammatory response such as NFKB1, TLR2, RXRA, and PLA2G4A [6].

Rumen-protected Met in the form of Smartamine $M$ (SM; Adisseo NA, Alpharetta, GA, USA) is effective in providing extra metabolizable Met to balance peripartal diets, which in turn helps to optimize DMI, milk production, and improve whole blood phagocytosis capacity [3]. Our hypothesis was that SM during the peripartal period alleviates the negative effects of a prepartal higher-energy diet on PMN function as well as blood and liver tissue immunometabolic biomarkers, which are ultimately reflected in an impaired postpartal performance. Furthermore, it was hypothesized that beneficial effects of SM would result in responses comparable to those detected in cows fed a prepartal lowerenergy diet. The hypothesis was addressed by measuring gene expression in PMN, biomarkers in blood and liver tissue, and performance.

\section{Methods}

Animals, experimental design, and animal management Animal handling procedures were performed in accordance with protocols approved by the University of Illinois Institutional Animal Care and Use Committee. Complete details of the experimental design have been reported previously [3, 13]. Although published separately, all dietary treatments were run concurrently. Briefly, a subset of cows from a group of 65 that remained healthy throughout the study with the most complete set of PMN samples (d -10, 3, and 21) during the transition period were selected. All cows in the experiment were fed a lowerenergy diet $\left(\mathrm{CON} ; \mathrm{NE}_{\mathrm{L}}=1.24 \mathrm{Mcal} / \mathrm{kg} \mathrm{DM}\right.$; no Met supplementation) for ad libitum intake during the far-off dry period (i.e., $\mathrm{d}-50$ to $\mathrm{d}-21$ ). During the close-up period (i.e., d $-21 \mathrm{~d}$ to calving), cows were randomly assigned either to a higher-energy diet $\left(\mathrm{OVE} ; \mathrm{NE}_{\mathrm{L}}=1.54 \mathrm{Mcal} / \mathrm{kg}\right.$ DM), OVE plus Smartamine M (OVE + SM; Adisseo NA) or remained on CON (Table 1). The same basal lactation $\operatorname{diet}\left(\mathrm{NE}_{\mathrm{L}}=1.75 \mathrm{Mcal} / \mathrm{kg} \mathrm{DM}\right)$ was fed to all cows postpartum until 30 DIM. The number of cows used in the present study was 9, 10, and 9 in OVE, OVE + SM, and CON. The SM (0.07\% of DM) was top-dressed during the entire experiment over the OVE or lactation diet from -21 DIM through 30 DIM. Consecutive morning, midday, and evening milk samples were harvested until 30 DIM. Composite milk samples were prepared in proportion to milk yield at each milking, preserved (800 Broad Spectrum Microtabs II; D \& F Control Systems Inc., Sab Ramon, $\mathrm{CA}$ ), and analyzed for contents of fat, protein, lactose, and SCC (Dairy Lab Services, Dubuque, IL). The SCC data were $\log 10$ transformed prior to statistical analysis. Performance data from all cows in CON and OVE have been published previously by Ji et al. (2012), and data from all cows in OVE and OVE + SM by Osorio et al. [3]. Therefore, in order to combine the performance data for CON, OVE, and OVE + SM they were re-analyzed using only cows from which PMN were isolated.

\section{Blood metabolites and liver composition}

Blood was sampled from the coccygeal vein at $d-21,-10$, 7,14 and 21 relative to parturition. Samples were collected into evacuated serum tubes (BD Vacutainer; BD and Co., Franklin Lakes, NJ) containing either clot activator or lithium heparin for serum and plasma, respectively. After blood collection, tubes with lithium heparin were placed on ice and tubes with clot activator were kept at $21{ }^{\circ} \mathrm{C}$ until centrifugation ( $\left.\sim 30 \mathrm{~min}\right)$. Serum and plasma were obtained by centrifugation at $1900 \times \mathrm{g}$ for $15 \mathrm{~min}$ at $4{ }^{\circ} \mathrm{C}$. Aliquots of serum and plasma were frozen $\left(-20{ }^{\circ} \mathrm{C}\right)$ until further analysis. Measurements of NEFA, BHBA and glucose were performed using commercial kits in an autoanalyzer at the University of Illinois Veterinary Diagnostic Laboratory (Urbana). Insulin concentration was quantified using a commercial bovine insulin ELISA kit (catalog no. 10-1201-01; Mercodia AB, Uppsala, Sweden). The concentration of very-lowdensity lipoproteins (VLDL) was determined using a high-density lipoprotein and low-density lipoprotein 
Table 1 Ingredient and chemical composition of diets

\begin{tabular}{|c|c|c|c|c|}
\hline \multirow[b]{2}{*}{ Item } & \multicolumn{3}{|c|}{ Close-up period $^{a}$} & \multirow[t]{2}{*}{ Lactation $^{\mathrm{b}}$} \\
\hline & $\mathrm{CON}$ & OVE & OVE + SM & \\
\hline \multicolumn{5}{|l|}{ Ingredient, \% of DM } \\
\hline Alfalfa silage & 12.00 & 8.20 & 8.20 & 5.00 \\
\hline Alfalfa hay & - & 3.50 & 3.50 & 4.00 \\
\hline Corn silage & 33.00 & 35.90 & 35.90 & 33.00 \\
\hline Wheat straw & 36.00 & 15.40 & 15.40 & 4.00 \\
\hline Cottonseed & - & - & - & 3.50 \\
\hline Wet brewers grains & - & 6.00 & 6.00 & 10.00 \\
\hline Ground shelled corn & 4.00 & 13.00 & 13.00 & 22.20 \\
\hline Soy hulls & 2.00 & 4.00 & 4.00 & 4.00 \\
\hline Soybean meal, 48 \% CP & 7.94 & 3.10 & 3.10 & 3.30 \\
\hline Expeller soybean meal ${ }^{c}$ & - & 2.00 & 2.00 & 6.20 \\
\hline SoyChlor ${ }^{d}$ & 0.15 & 3.80 & 3.80 & - \\
\hline Blood meal, 85 \% CP & 1.00 & 1.00 & 1.00 & 0.30 \\
\hline Smartamine $\mathrm{M}^{\mathrm{e}}$ & - & - & 0.07 & - \\
\hline Urea & 0.45 & 0.30 & 0.30 & 0.14 \\
\hline Rumen-inert fat ${ }^{f}$ & - & - & - & 1.00 \\
\hline Limestone & 1.30 & 1.30 & 1.30 & 1.18 \\
\hline Salt (plain) & 0.32 & 0.30 & 0.30 & 0.27 \\
\hline Dicalcium phosphate & 0.12 & 0.18 & 0.18 & 0.27 \\
\hline Magnesium oxide & 0.21 & 0.08 & 0.08 & 0.14 \\
\hline Magnesium sulfate & 0.91 & 0.97 & 0.97 & - \\
\hline Sodium bicarbonate & - & - & - & 0.75 \\
\hline Potassium carbonate & - & - & - & 0.10 \\
\hline Calcium sulfate & - & - & - & 0.10 \\
\hline Mineral-vitamin mix $^{\mathrm{g}}$ & 0.20 & 0.20 & 0.20 & 0.20 \\
\hline Vitamin $A^{h}$ & 0.015 & 0.015 & 0.015 & - \\
\hline Vitamin $D^{i}$ & 0.025 & 0.025 & 0.025 & - \\
\hline Vitamin $\mathrm{E}^{\mathrm{j}}$ & 0.38 & 0.38 & 0.38 & - \\
\hline Biotin & - & 0.35 & 0.35 & 0.35 \\
\hline $\mathrm{DM}^{\mathrm{k}}, \%$ & $46.6 \pm 0.8$ & $45.2 \pm 0.8$ & $45.2 \pm 0.8$ & $45.2 \pm 1.5$ \\
\hline \multicolumn{5}{|l|}{ Chemical analysis, $\%$} \\
\hline $\mathrm{NE}_{\mathrm{L}}, \mathrm{Mcal} / \mathrm{kg}$ & 1.24 & 1.47 & 1.47 & 1.65 \\
\hline$C P, \%$ of $D M$ & 14.6 & 15.6 & 15.6 & 16.3 \\
\hline$A D F, \%$ of $D M$ & 36.2 & 30.2 & 30.2 & 24.1 \\
\hline NDF, $\%$ of DM & 52.7 & 44.7 & 44.7 & 37.9 \\
\hline
\end{tabular}

${ }^{a}$ The control diet (CON) was fed to all cows during the far-off dry period $(-50$ to $-21 \mathrm{~d}$ relative to expected calving). During the close-up period (-21 $d$ to calving) cows were assigned either to a higher-energy diet (OVE), OVE plus Smartamine M (OVE + SM) or continuously fed the CON diet

${ }^{b}$ All cows received the same lactation diet; however, Smartamine M $0.07 \%$ of DMI) supplementation to the OVE + SM diet continued until 30 DIM

'SoyPLUS (West Central Soy, Ralston, IA, USA)

${ }^{\mathrm{d}}$ SoyChlor (West Central Soy, Ralston, IA, USA)

eSmartamine M (Adisseo NA, Alpharetta, GA, USA)

fEnergy Booster 100 (MSC, Carpentersville, IL, USA)

${ }^{9}$ Contained a minimum of $5 \% \mathrm{Mg}, 10 \% \mathrm{~S}, 7.5 \% \mathrm{~K}, 2.0 \% \mathrm{Fe}, 3.0 \% \mathrm{Zn}, 3.0 \% \mathrm{Mn}$, $5000 \mathrm{mg}$ of Cu/kg, $250 \mathrm{mg}$ of $\mathrm{l} / \mathrm{kg}, 40 \mathrm{mg}$ of Co/kg, $150 \mathrm{mg}$ of Se/ $/ \mathrm{kg}, 2200 \mathrm{kIU}$ of vitamin $\mathrm{A} / \mathrm{kg}, 660 \mathrm{klU}$ of vitamin D3/kg, and $7700 \mathrm{IU}$ of vitamin $\mathrm{E} / \mathrm{kg}$

${ }^{\mathrm{h}}$ Contained $30,000 \mathrm{klU} / \mathrm{kg}$

'Contained $5009 \mathrm{kIU} / \mathrm{kg}$

${ }^{\mathrm{j}}$ Contained 44,000 IU/kg

${ }^{\mathrm{k}}$ Means $\pm \mathrm{SD}$
(LDL)/VLDL cholesterol quantification kit (catalog no. K613-100; BioVision Inc., Mountain View, CA).

Liver biopsies were harvested at $\mathrm{d}-10,7$, and 21 relative to parturition from cows under local anesthesia using the same procedures as described previously (Osorio et al., 2013). Liver was frozen immediately in liquid nitrogen and stored until further analysis for concentration of total lipid [16] and triacylglycerol (TAG) [17, 18].

\section{PMN isolation}

Neutrophils were isolated based on procedures described by Moyes et al. [19] with modifications. Briefly, blood $(\sim 120 \mathrm{~mL})$ was sampled from the coccygeal vein before morning feeding at $-10,3$, and $21 \mathrm{~d}$ in ACD Vacutainer tubes and mixed well by inversion and placed on ice until isolation. Samples were centrifuged at $600 \times g$ for $30 \mathrm{~min}$ at $4{ }^{\circ} \mathrm{C}$. The plasma, buffy coat, and approximately one-third of the red blood cells were discarded. The remaining sample was poured into a $50-\mathrm{mL}$ conical tube (Fisher Scientific, Pittsburgh, PA). Twenty-five milliliters of deionized water at $4{ }^{\circ} \mathrm{C}$ was added to lyse red blood cells, followed by addition of $5 \mathrm{~mL}$ of $5 \times \mathrm{PBS}$ at $4{ }^{\circ} \mathrm{C}$ to restore an iso-osmotic environment. Samples were centrifuged at $200 \times g$ for $10 \mathrm{~min}$ at $4{ }^{\circ} \mathrm{C}$ and the supernatants were decanted. The pellet was washed with $10 \mathrm{~mL}$ of $1 \times$ PBS and centrifuged for $5 \mathrm{~min}$ $\left(200 \times g\right.$ at $\left.4{ }^{\circ} \mathrm{C}\right)$ and supernatants were decanted. Eight milliliters of deionized water at $4{ }^{\circ} \mathrm{C}$ was added, followed by addition of $2 \mathrm{~mL}$ of $5 \times \mathrm{PBS}$ at $4{ }^{\circ} \mathrm{C}$. Samples were centrifuged at $500 \times g$ for $5 \mathrm{~min}$ at $4{ }^{\circ} \mathrm{C}$ and supernatant was decanted. Two subsequent washings using $10 \mathrm{~mL}$ of $1 \times \mathrm{PBS}$ at $4{ }^{\circ} \mathrm{C}$ were performed with samples centrifuged at $500 \times g$ for $5 \mathrm{~min}$ at $4{ }^{\circ} \mathrm{C}$ and supernatant was decanted. Although no cell differential was performed, this protocol routinely results in $>88 \%$ of isolated cells as neutrophils [19-21]. Neutrophils were immediately homogenized in $2 \mathrm{~mL}$ of Trizol Reagent (Invitrogen, Carlsbad, CA) with $1 \mu \mathrm{L}$ of liner acrylamide (Ambion Inc., Austin, TX) using a Polytron power homogenizer at maximum speed. The suspension was transferred equally into 2 RNA-free microcentrifuge tubes (2 mL; Fisher Scientific) and stored at $-80^{\circ} \mathrm{C}$ until further analysis.

\section{Whole blood phagocytosis}

Details of the phagocytosis procedure were reported previously [3]. The phagocytic capacity of heparinized whole blood was determined using the Phagotest kit (Orpegen Pharma, Heidelberg, Germany) following the manufacturer's instructions. In brief, $20 \mu \mathrm{L}$ of bacteria Escherichia coli was added to 1 of 3 whole blood samples $(100 \mu \mathrm{L} ; 1$ control and 2 test samples) in test tubes (Falcon, Becton Dickinson, Franklin Lakes, NJ) and incubated for $10 \mathrm{~min}$ at $37^{\circ} \mathrm{C}$. The cells were resuspended in 
$200 \mu \mathrm{L}$ of DNA-staining solution, and light-protected in an ice bath until analyzed by flow cytometry (LSR II, Becton Dickinson, San Jose, CA).

\section{RNA extraction, primer design and evaluation, and quantitative PCR}

Specific details of RNA extraction from PMN, primer design and evaluation, cDNA synthesis, and quantitative reverse transcription PCR are presented in the Additional File. Briefly, RNA samples were extracted from PMN using Qiazol reagent combination with miRNeasy ${ }^{\circ}$ Mini Kit (Cat. \#217004, Qiagen). The quality of RNA evaluated by RNA integrity number (RIN) in the 2100 Bioanalyzer (Agilent Technologies Inc., Santa Clara, CA) was above 6.50. Based on relevant biological functions in PMN, 16 target genes selected in this study are involved in metabolism, inflammation, oxidative stress, and cellular receptors. The official symbol, name, and a short summary description of these genes are presented in Additional file 1: Table S1. Primers were designed via Primer Express 3.0.1 software (Applied Biosystems).

Quantitative PCR (qPCR) was performed by ABI Prism 7900 HT SDS instrument (Applied Biosystems). Details of primer sequences and amplicon size, primer product sequencing information, and qPCR performance are presented in Additional file 1: Table S2, S3, S4, and S5. We used three genes as internal controls (ICG), oxysterolbinding protein-like 2 (OSBPL2), golgin subfamily $\mathrm{A}$, member 5 (GOLGA5), and single-strand-selective monofunctional uracil-DNA glycosylase 1 (SMUG1). These were previously confirmed as stably expressed for PMN gene expression [19]. The final gene expression data were normalized with the geometric mean of the 3 ICG.

\section{Statistical analysis}

Gene expression data were normalized by logarithmic transformation prior to statistical analysis. Data were analyzed with the Proc MIXED procedure of SAS 9.4 (SAS Institute Inc., Cary, NC) using diet, time, and diet $\times$ time as fixed effects and cow as random effect. The exponential correlation covariance structure SP for repeated measures was used for analysis of gene expression and phagocytosis data with the following model:

$$
y_{i j k}=\mu+D_{i}+T_{j}+D T_{i j}+\alpha_{k}+e_{i j k}
$$

Where $y_{i j k}$ is the dependent, continuous variable; $\mu$ is the general mean; $\mathrm{D}_{\mathrm{i}}$ is the fixed effect of the diet $(i=1$, 2 , or 3 , namely, CON, OVE or OVE $+\mathrm{SM}) ; \mathrm{T}_{\mathrm{j}}$ is the fixed effect of the time $(j=1,2$, or 3 , namely, $-10,3$, or 21 DIM); $\mathrm{DT}_{\mathrm{ij}}$ is the fixed effect of the $i$ th treatment by the $j$ th time of the interaction; $\alpha_{k}$ is the random effect of the individual; $\mathrm{e}_{\mathrm{ijk}}$ is the random residual. For data of DMI, SCC, milk yield, and milk composition, which were equally-spaced, an autoregressive 1 covariance structure was used while the exponential correlation covariance structure SP (POW) was used for unequally spaced data from liver composition and blood metabolites.

\section{Results \\ Performance and phagocytosis}

The complete set of milk yield, milk composition, and DMI data for the entire group of cows in CON, OVE, and OVE + SM have already been published by Osorio et al. [3] and Ji et al. [13]. Only performance data from cows used for PMN extraction were utilized in the present analysis. Results for peripartal performance including milk yield and components, SCC, ECM, DMI, and whole blood phagocytosis are presented in Table 2 and Fig. 1a-d. There was a $\mathrm{D} \times \mathrm{T}(P=0.01)$ for $\mathrm{DMI}$ postpartum mainly due to a slower increment in DMI of OVE cows after $6 \mathrm{~d}$ postpartum. The latter was reflected in ca. $5.3 \mathrm{~kg} / \mathrm{d}$ lower $(P<0.01) \mathrm{DMI}$ in OVE than CON and $\mathrm{OVE}+\mathrm{SM}$, while no differences were observed between $\mathrm{CON}$ vs. OVE + SM. In contrast to DMI postpartum, prepartal DMI was not affected by diet or $\mathrm{D} \times \mathrm{T}$.

There were $\mathrm{D} \times \mathrm{T}$ observed for milk protein $(P=0.02)$ and milk fat $(P=0.09)$, mainly attributed to greater $(P<0.01)$ concentration in OVE + SM than other treatments during the 1 st wk of lactation. Milk yield was greater $(P=0.07)$ in CON and OVE + SM cows compared with OVE, while ECM $(P=0.06)$ was lower in OVE than $\mathrm{OVE}+\mathrm{SM}$ but similar compared with CON. In addition, milk yield $(P<0.01)$ and ECM $(P=0.02)$ increased over time, while milk fat $(P<0.01)$ and milk protein $(P<0.01)$ decreased (Fig. 1a, c, d).

The SCC was lower in cows fed OVE + SM than CON and OVE $(P<0.04)$, while CON vs. OVE had similar SCC. Additionally, SCC declined $(P<0.01)$ over time after calving for all treatments. There was greater $(P<0.01)$ phagocytosis in whole blood of $\mathrm{CON}$ cows compared with OVE and OVE + SM, while OVE + SM cows had greater $(P=0.01)$ phagocytosis than OVE. In contrast to SCC, whole blood phagocytosis was not affected by time.

\section{Blood biomarkers and liver composition}

A $\mathrm{D} \times \mathrm{T}$ interaction was detected for insulin and NEFA concentration $(P<0.01$; Table 2 and Fig. $2 \mathrm{a}, \mathrm{b})$. Feeding OVE + SM compared with OVE and CON led to greater $(P<0.02)$ insulin concentration after parturition, while cows in OVE compared with CON had greater $(P<0.01)$ insulin at $\mathrm{d} 7$ and 21. Cows fed OVE $+\mathrm{SM}$ had lower $(P=0.03)$ NEFA at $\mathrm{d}-21$ in comparison to OVE and CON, follow by lower NEFA in OVE and OVE + SM in comparison to $\mathrm{CON}$ at $\mathrm{d}-10(P=0.02)$ compared with $\mathrm{CON}$, and at $\mathrm{d}-21$. The concentration of BHBA was not affected $(P>0.05)$ by treatments. 
Table 2 Effects of different treatments on production responses, somatic cell counts (SCC), whole blood phagocytosis, and blood and liver tissue biomarkers in Holstein cows fed a lower-energy diet (CON), higher-energy diet (OVE) or OVE plus Smartamine M $(\mathrm{OVE}+\mathrm{SM})$ during the close-up period and through the first $30 \mathrm{~d}$ postpartum

\begin{tabular}{|c|c|c|c|c|c|c|c|}
\hline \multirow[t]{2}{*}{ Item $^{d}$} & \multicolumn{3}{|c|}{ Treatment $^{\mathrm{a}}$} & \multirow[t]{2}{*}{$\mathrm{SEM}^{\mathrm{b}}$} & \multicolumn{3}{|c|}{$P$-value } \\
\hline & $\overline{\mathrm{CON}}$ & OVE & $\mathrm{OVE}+\mathrm{SM}$ & & Diet & Time & $\mathrm{D} \times \mathrm{T}^{\mathrm{C}}$ \\
\hline Milk yield, kg/d & $40.97^{e}$ & $34.04^{f}$ & $41.43^{e}$ & 2.59 & 0.07 & $<0.01$ & 0.74 \\
\hline $\mathrm{ECM}, \mathrm{kg} / \mathrm{d}$ & $44.82^{e, f}$ & $40.02^{f}$ & $46.90^{\mathrm{e}}$ & 2.26 & 0.06 & 0.02 & 0.17 \\
\hline \multicolumn{8}{|l|}{$\mathrm{DMl}, \mathrm{kg} / \mathrm{d}$} \\
\hline Prepartum & 11.52 & 12.57 & 12.64 & 0.57 & 0.22 & $<0.01$ & 0.76 \\
\hline Postpartum & $16.19^{e}$ & $11.28^{f}$ & $16.94^{e}$ & 1.22 & $<0.01$ & $<0.01$ & 0.01 \\
\hline Feed efficiency & $2.53^{f}$ & $3.01^{e}$ & $2.47^{f}$ & 0.15 & 0.03 & $<0.01$ & 0.01 \\
\hline Milk fat, \% & 4.60 & 4.58 & 4.75 & 0.18 & 0.76 & $<0.01$ & 0.09 \\
\hline Milk protein, \% & 3.10 & 3.05 & 3.20 & 0.09 & 0.44 & $<0.01$ & 0.02 \\
\hline Log-transformed SCC & $4.95^{\mathrm{e}}$ & $4.92^{e}$ & $4.63^{f}$ & 0.10 & 0.06 & $<0.01$ & 0.90 \\
\hline Whole blood phagocytosis, $\%$ & $77.35^{\mathrm{e}}$ & $41.81^{9}$ & $51.28^{f}$ & 3.38 & $<0.01$ & 0.58 & 0.75 \\
\hline \multicolumn{8}{|l|}{ Blood biomarkers } \\
\hline Insulin, $\mu \mathrm{g} / \mathrm{L}^{\mathrm{h}}$ & $-1.66^{f}$ & $-1.30^{f}$ & $-0.83^{e}$ & 0.19 & 0.01 & $<0.01$ & $<0.01$ \\
\hline NEFA, $\mathrm{mEq} / \mathrm{L}^{\mathrm{h}}$ & -0.77 & -0.96 & -1.02 & 0.10 & 0.16 & $<0.01$ & $<0.01$ \\
\hline BHBA, $\mathrm{mmol} / \mathrm{L}^{\mathrm{h}}$ & -0.39 & -0.37 & -0.52 & 0.08 & 0.30 & $<0.01$ & 0.11 \\
\hline Glucose, mg/dL & $57.8^{e}$ & $54.6^{\mathrm{e}, \mathrm{f}}$ & $53.5^{f}$ & 1.55 & 0.07 & $<0.01$ & 0.54 \\
\hline$V L D L, \mu g / \mu \mathrm{L}$ & $0.37^{f}$ & $0.43^{e, f}$ & $0.49^{e}$ & 0.04 & 0.01 & $<0.01$ & 0.25 \\
\hline \multicolumn{8}{|l|}{ Liver composition, \% wet wt } \\
\hline Total lipid ${ }^{\mathrm{h}}$ & 6.9 & 9.2 & 7.7 & 1.13 & 0.14 & $<0.01$ & 0.37 \\
\hline TAG & $2.47^{f}$ & $4.70^{e}$ & $3.40^{e, f}$ & 0.65 & 0.03 & $<0.01$ & 0.15 \\
\hline 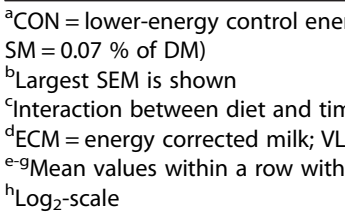 & $24 \mathrm{Mca}$ & $\mathrm{E}=\mathrm{hig}$ & $\begin{array}{l}\text { cerol } \\
P<0.05)\end{array}$ & & & & \\
\hline
\end{tabular}

Feeding OVE and OVE + SM compared with CON tended $(P=0.07)$ to decrease overall glucose concentration (Table 2). Although total lipid concentration in liver was not affected $(P>0.05)$ by treatments, the diet effect $(P=0.03)$ in concentration of TAG was reflected in lower TAG in cows fed CON $(P=0.01)$ and OVE + SM $(P=0.08)$ compared with OVE (Table 2). The concentration of VLDL was greater $(P=0.03)$ in OVE + SM fed cows compared with CON.

\section{Target gene expression}

For most of the genes evaluated an interaction diet $x$ time was observed, which based on the data was most likely associated with the different response over time between the CON and OVE + SM group.

\section{Met and glutathione metabolism}

A $\mathrm{D} \times \mathrm{T}$ interaction was observed for GPX1 $(P=0.05)$, $\operatorname{AHCY}(P=0.10)$ and GSR $(P=0.06$; Table 3 and Fig. 3a-c $)$.
The expression of $A H C Y$ was lower $(P=0.02)$ in $C O N$ than OVE and OVE + SM, while expression was similar between OVE and OVE + SM cows. The expression of GPX1 was lower in OVE + SM compared with CON $(P=0.01)$ and $\operatorname{OVE}(P=0.01)$ at $-10 \mathrm{~d}$ postpartum, and postpartal expression of GPX1 was similar among treatments. At $21 \mathrm{~d}$ postpartum, CON cows had a lower expression of GSR compared with OVE $(P=0.07)$ and OVE + SM $(P<0.01)$, but GSR expression was similar between OVE and OVE + SM.

\section{Inflammation}

A D $\times \mathrm{T}$ interaction was observed for STAT3 $(P=0.07)$, TLR4 $(P=0.06)$, LTA4H $(P=0.01)$ and RXRA $(P=0.03$; Table 3 and Fig. $4 \mathrm{a}-\mathrm{d})$. A markedly lower $(P<0.01)$ expression of $L T A 4 H$ at $-10 \mathrm{~d}$ was observed in OVE + SM and OVE than CON fed cows. The mRNA expression of TLR4 was greater $(P=0.01)$ in OVE than OVE + SM cows at $3 \mathrm{~d}$, while TLR4 expression in OVE + SM cows 


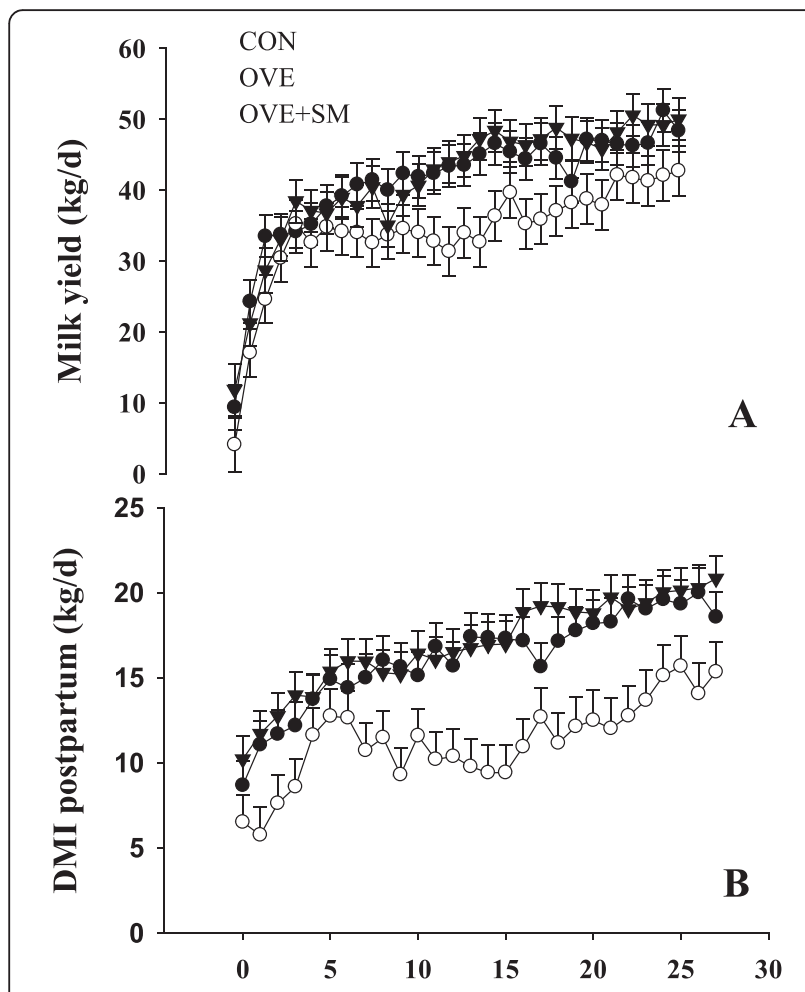

Day relative to parturition

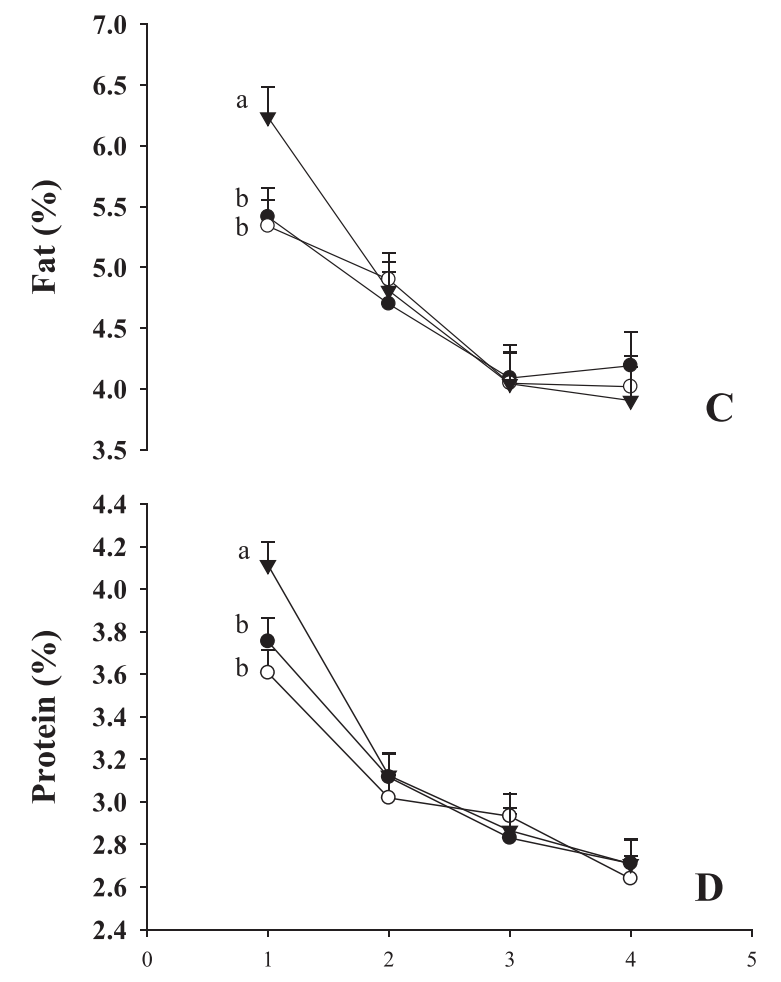

Week relative to parturation
Fig. 1 Postpartal milk yield (panel a), DMI (panel b), milk fat (panel c) and protein (panel d) content in Holstein cows fed a lower-energy control diet (CON), higher-energy diet (OVE) or OVE plus Smartamine $\mathrm{M}(\mathrm{OVE}+\mathrm{SM})$ during the close-up period and through the first $30 \mathrm{~d}$ postpartum. ${ }^{a-b}$ Effect of diet $(P<0.10)$ at a specific time point

was similar to $C O N$ at the same time point. The expression of STAT3 and RXRA was upregulated in OVE + SM cows than CON $(P=0.05)$. STAT3 mRNA expression was similar between OVE and OVE + SM at $21 \mathrm{~d}$ postpartum, while RXRA mRNA expression was greater in OVE + SM than OVE at the same time point. The diet effect $(P<0.01)$ observed in NFKB1 and TNFA was reflected in a greater mRNA expression of NFKB1 $(P<0.01)$ and TNFA $(P<0.01)$ in OVE and OVE + SM cows compared with CON. The diet effect $(P=0.07)$ observed in TLR4 was associated with a greater $(P=0.05)$ expression in $\mathrm{OVE}+\mathrm{SM}$ than $\mathrm{CON}$, while similar expression was observed between OVE $+\mathrm{SM}$ and OVE.

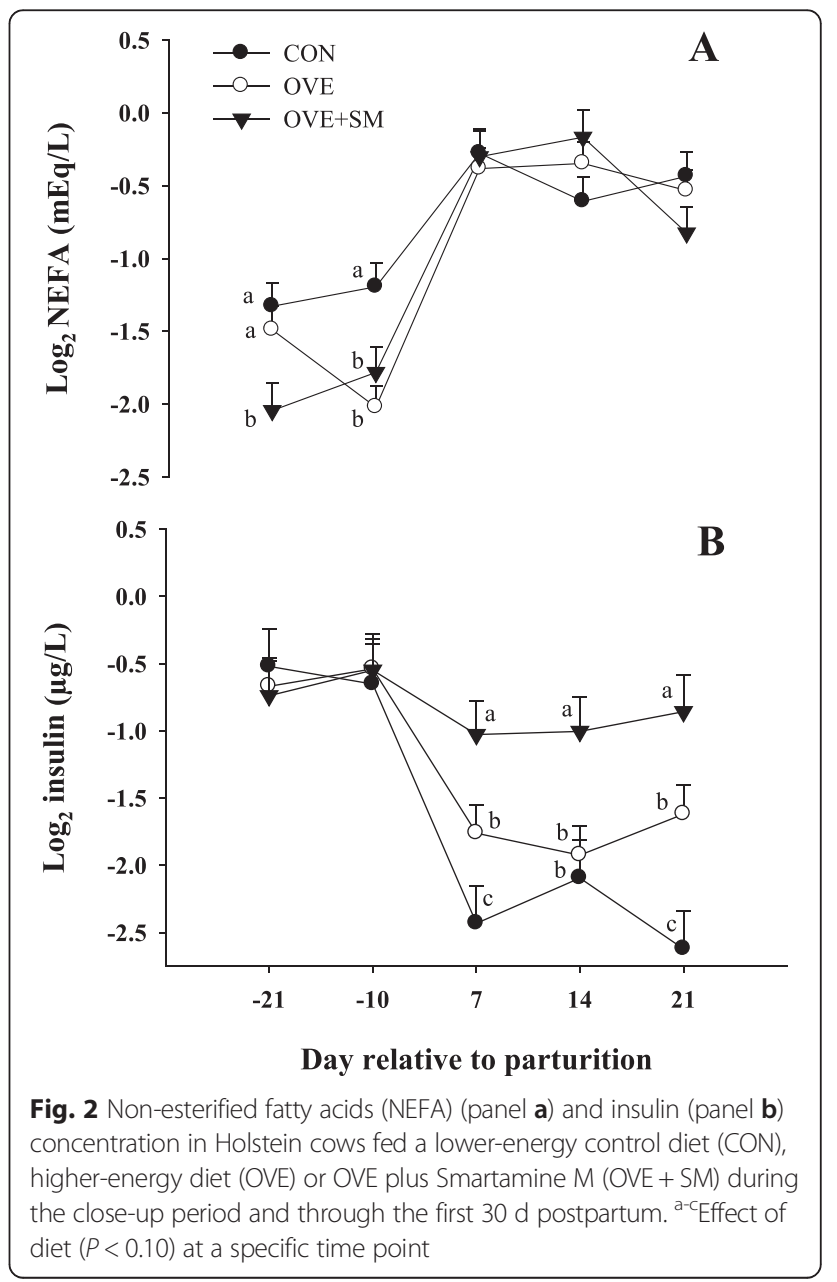


Table 3 Expression of target genes in PMN isolated on $-10,+3$, and $21 \mathrm{~d}$ around parturition in Holstein cows fed a lowerenergy control diet (CON), a higher-energy diet (OVE) or OVE plus Smartamine M (OVE + SM) during the close-up period and through the first $30 \mathrm{~d}$ postpartum

\begin{tabular}{|c|c|c|c|c|c|c|c|}
\hline \multirow[t]{2}{*}{ Gene } & \multicolumn{3}{|c|}{ Treatment $^{\mathrm{a}}$} & \multirow[t]{2}{*}{$\mathrm{SEM}^{\mathrm{b}}$} & \multicolumn{3}{|c|}{$P$-value } \\
\hline & $\mathrm{CON}$ & OVE & $\mathrm{OVE}+\mathrm{SM}$ & & Diet & Time & $D \times T^{c}$ \\
\hline \multicolumn{8}{|c|}{ Met and glutathione metabolism } \\
\hline AHCY & $5.23^{e}$ & $13.47^{d}$ & $12.23^{\mathrm{d}}$ & 2.47 & 0.02 & 0.67 & 0.10 \\
\hline GSR & 5.76 & 9.21 & 10.12 & 2.02 & 0.28 & 0.34 & 0.06 \\
\hline GPX1 & 9.82 & 9.02 & 7.66 & 0.94 & 0.24 & 0.04 & 0.05 \\
\hline \multicolumn{8}{|c|}{ Inflammation } \\
\hline NFKB1 & $7.80^{\mathrm{e}}$ & $17.58^{\mathrm{d}}$ & $19.24^{d}$ & 3.60 & $<0.01$ & 0.80 & 0.98 \\
\hline STAT3 & 8.37 & 11.40 & 10.46 & 1.80 & 0.48 & 0.87 & 0.07 \\
\hline TLR4 & $-4.28^{\mathrm{e}}$ & $-3.20^{\mathrm{d}, \mathrm{e}}$ & $-2.94^{\mathrm{d}}$ & 0.57 & 0.07 & 0.96 & 0.06 \\
\hline TNF & $-3.34^{e}$ & $5.91^{d}$ & $6.36^{d}$ & 2.05 & $<0.01$ & 0.66 & 0.77 \\
\hline LTA4H & 0.08 & 0.06 & 0.05 & 0.01 & 0.26 & 0.46 & 0.01 \\
\hline$R X R A$ & 11.32 & 12.94 & 13.39 & 1.59 & 0.61 & 0.11 & 0.03 \\
\hline \multicolumn{8}{|c|}{ Cellular receptors } \\
\hline SELL & 2.38 & 5.04 & 4.93 & 1.23 & 0.23 & 0.62 & $<0.01$ \\
\hline ITGAM & $5.04^{e}$ & $10.69^{d}$ & $10.37^{d}$ & 1.73 & 0.04 & 0.07 & 0.07 \\
\hline TLN1 & 12.53 & 9.77 & 10.08 & 1.11 & 0.18 & 0.24 & 0.07 \\
\hline$V C L$ & $-5.00^{\mathrm{e}}$ & $-3.98^{\mathrm{d}}$ & $-4.24^{d}$ & 0.26 & 0.02 & $<0.01$ & $<0.01$ \\
\hline \multicolumn{8}{|c|}{ Oxidative stress } \\
\hline SOD1 & 7.09 & 9.93 & 10.31 & 1.98 & 0.34 & 0.36 & 0.10 \\
\hline SOD2 & $-0.68^{\mathrm{e}}$ & $-0.83^{e}$ & $0.21^{d}$ & 0.32 & 0.06 & 0.04 & 0.08 \\
\hline S100A8 & 8.88 & 7.28 & 6.96 & 0.88 & 0.25 & 0.25 & 0.04 \\
\hline
\end{tabular}

${ }^{\mathrm{a}} \mathrm{CON}=$ lower-energy control $(n=9 ; 1.24 \mathrm{Mcal} / \mathrm{kg} \mathrm{DM}) ; \mathrm{OVE}=$ higher-energy $(n=9 ; 1.54 \mathrm{Mcal} / \mathrm{kg} \mathrm{DM}) ;$ OVE + SM = higher-energy plus Smartamine M $(n=10$; $\mathrm{SM}=0.07 \%$ of $\mathrm{DM}$ )

bLargest SEM is shown

' Interaction between diet and time

${ }^{d-e}$ Mean values within a row with different superscripts were significantly different $(P<0.05)$

\section{Cellular receptors}

We observed a $\mathrm{D} \times \mathrm{T}$ interaction for the expression of SELL $(P<0.01)$, ITGAM $(P=0.07)$, TLN1 $(P=0.07)$ and $V C L(P<0.01$; Table 3 and Fig. 5a-d). The expression of ITGAM was greater $(P=0.01)$ in OVE than $\mathrm{CON}$ at -10 $\mathrm{d}$, while expression in CON and OVE + SM was similar at the same time. The expression of ITGAM and SELL was greater in OVE + SM than CON $(P=0.01)$ and OVE $(P<0.01)$ cows at $21 \mathrm{~d}$ postpartum. The previous response in ITGAM was reflected in a diet effect $(P=0.04)$ were greater $(P=0.03)$ expression was observed in OVE and OVE + SM than CON. The expression of TLN1 was markedly lower $(P=0.02)$ in OVE $+\mathrm{SM}$ than CON fed cows at $-10 \mathrm{~d}$, whereas expression in OVE $+\mathrm{SM}$ and OVE were similar. The TLN1 was followed by lower $(P=0.05)$ expression in OVE than CON and OVE + SM at $21 \mathrm{~d}$ postpartum. Expression of $V C L$ was drastically down-

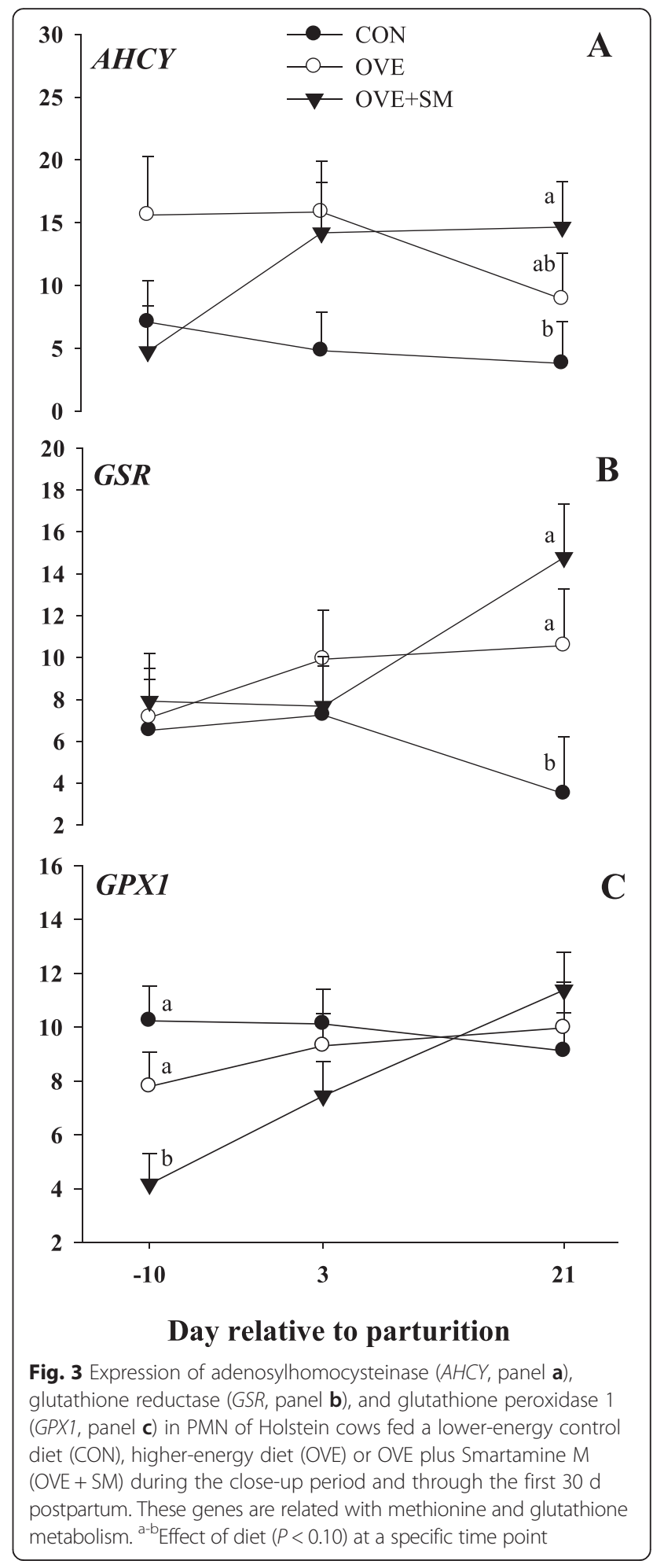

regulated in CON cows compared with OVE and OVE + SM $(P<0.01)$ cows at $3 \mathrm{~d}$ postpartum. Similarly to ITGAM, a diet effect $(P=0.02)$ was observed for $V C L$ expression, where OVE and OVE + SM had greater expression than $\operatorname{CON}(P=0.05)$. 


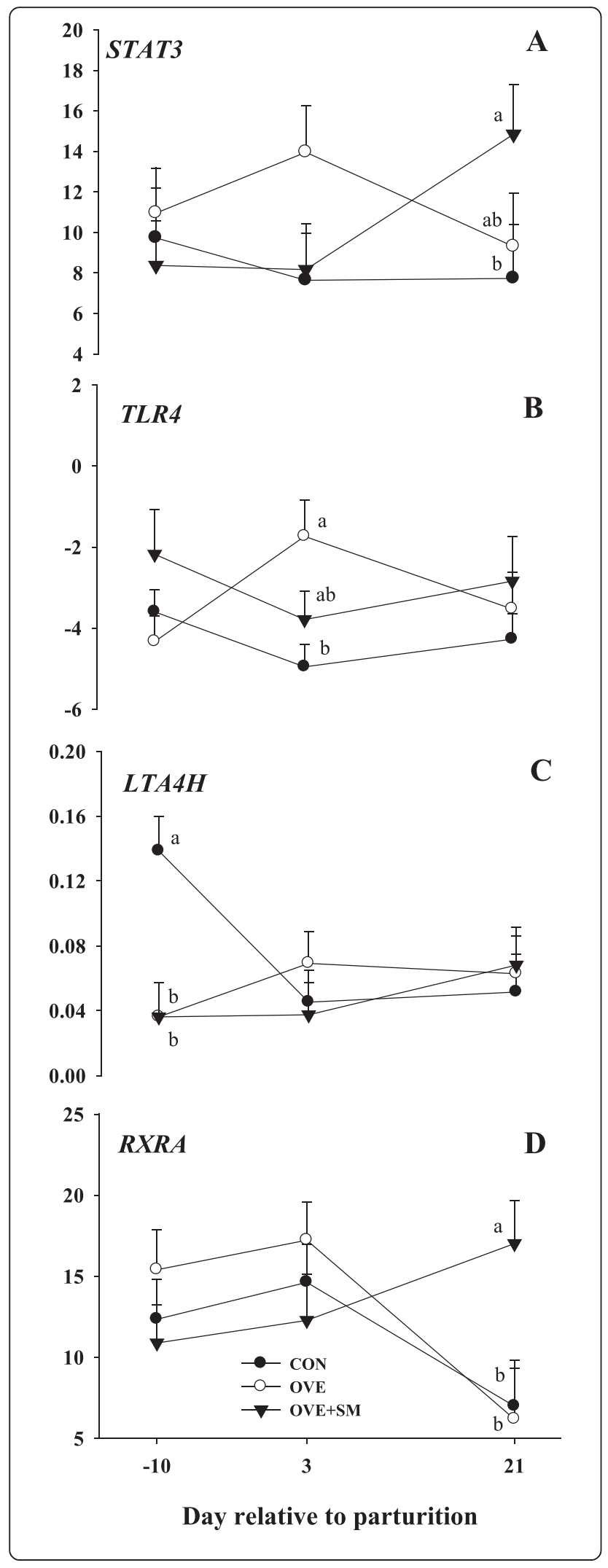

Fig. 4 Expression of signal transducer and activator of transcription 3 (STAT3, panel a), Toll-like receptor 4 (TLR4, panel b), leukotriene A4 hydrolase (LTA4H, panel $\mathbf{c}$ ), and retinoid $X$ receptor, alpha (RXRA, panel d) in PMN of Holstein cows fed a lower-energy control diet (CON), higher-energy diet (OVE) or OVE plus Smartamine M (OVE + SM) during the close-up period and through the first $30 \mathrm{~d}$ postpartum. These genes are related with inflammation and gene transcription. ${ }^{\text {abb }}$ Effect of diet $(P<0.10)$ at a specific time point

\section{Oxidative stress}

A $\mathrm{D} \times \mathrm{T}$ interaction was observed for SOD1 $(P=0.10)$, SOD2 $(P=0.08)$, and S100A8 $(P=0.04$; Table 3 and Fig. $6 \mathrm{a}-\mathrm{c})$. Expression of SOD2 was greater $(P=0.05)$ in OVE + SM than OVE cows at $-10 \mathrm{~d}$, while expressions in OVE and CON were similar. The expression of SOD1 and SOD2 was up-regulated in OVE + SM cows than CON $(P=0.02)$ and OVE $(P=0.09)$ at $21 \mathrm{~d}$ postpartum. The mRNA expression of $S 100 A 8$ was lower $(P<0.03)$ in OVE + SM than CON, while expression was similar between OVE and CON at $-10 \mathrm{~d}$. Similarly to prepartal expression of SOD2, the expression of S100A8 was greater $(P=0.04)$ in OVE + SM than OVE at $21 \mathrm{~d}$ postpartum, while expression was similar between OVE and CON.

\section{Discussion}

\section{Performance}

Overfeeding dairy cows in the prepartum period typically increases NEFA concentration and liver TAG accumulation postpartum [12], which consequently can decrease milk yield, DMI, health status and reproductive performance [22]. Supplementing the diet with rumenprotected methyl donors (e.g. choline, Met) has sometimes resulted in lower liver TAG [23-25], due to an increase in phosphatidylcholine synthesis [26], which is a main constituent of VLDL [27]. Thus, the greater milk yield in OVE + SM than OVE could be attributed at least in part to a better health status of the liver which may have allowed cows to achieve a greater DMI. This hypothesis is partially supported by the lower liver TAG concentration and coupled with greater VLDL synthesis and export indicated by the greater blood VLDL concentration between OVE + SM vs CON but not OVE vs CON. The similar performance between $\mathrm{CON}$ and OVE + SM supports the idea that Met supplementation allowed cows to overcome the negative effects of the prepartal higher-energy diet. The greater ECM yield in OVE + SM cows compared with OVE was driven by the greater milk protein and milk fat response elicited by feeding SM [3].

\section{SCC and PMN phagocytosis}

Phagocytosis is a key function of PMN, which are involved in host defense [28]. The Met supplied by the 


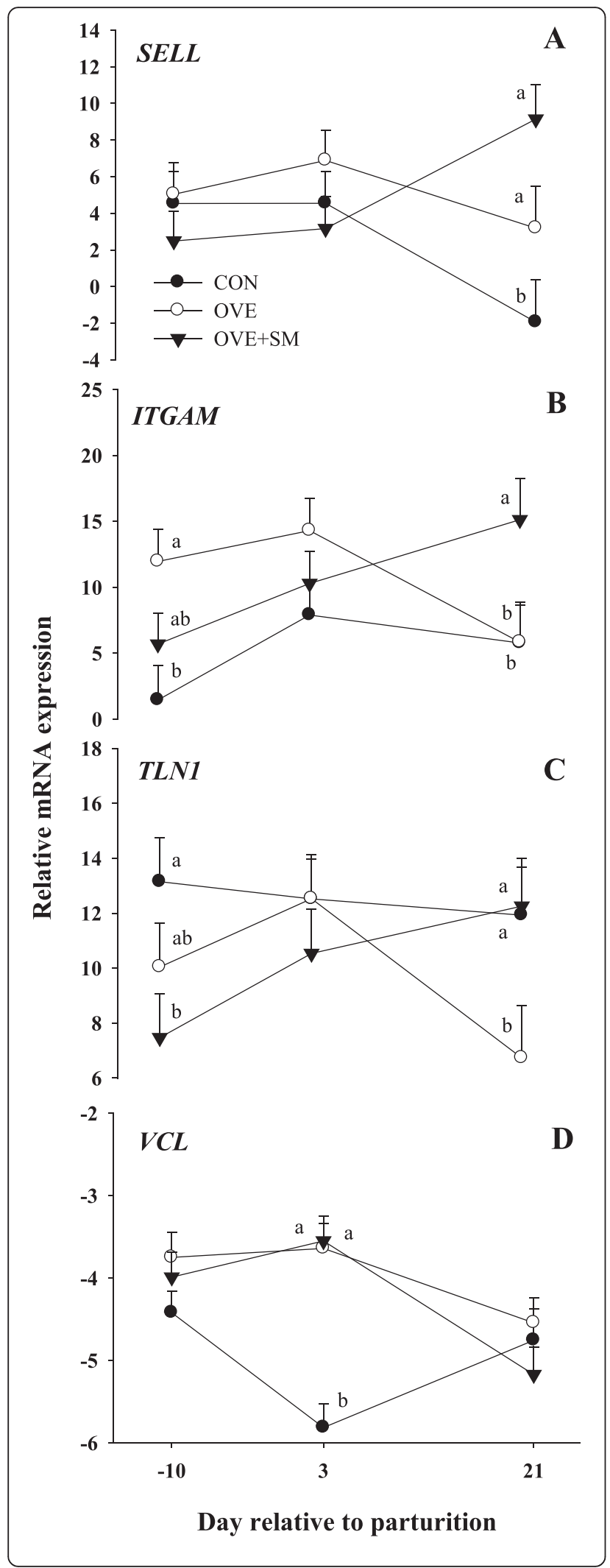

Fig. 5 Expression of selectin $L$ (SELL, panel a), integrin, alpha $M$ (ITGAM, panel b), talin 1 (TLN1, panel c), and vinculin (VCL, panel d) in PMN of Holstein cows fed a lower-energy control diet (CON), higherenergy diet (OVE) or OVE plus Smartamine M (OVE + SM) during the close-up period and through the first $30 \mathrm{~d}$ postpartum. These genes are related with cellular receptors of PMN. ${ }^{\text {a-b }}$ Effect of diet $(P<0.10)$ at a specific time point

basal OVE diet along with tissue mobilization might not be sufficient to meet the demand by the immune system for sulphur amino acids, which is of central importance given that overfeeding dietary energy also could impair function of the immune system $[6,19]$. It is well-established that metabolic products of Met metabolism, e.g. homocysteine, taurine and glutathione, play an important role in maintaining and supporting immune function [29]. The immunomodulatory properties of these compounds are underscored by the decrease in lymphocyte number and phagocytosis during taurine deprivation [30] as well as an increase in PMN adhesion when homocysteine concentration increased [30]. Furthermore, the antioxidant capacity of taurine and glutathione influences immune function by modulating the actions of reactive oxygen metabolites on transcription factor activation [31]. The whole blood phagocytic capacity detected in OVE + SM compared with OVE and CON provides evidence that enhancing Met supply could "boost" the immune system, hence, alleviating the negative effects of overfeeding energy in the dry period.

During mastitis, bacteria release toxins that activate macrophages and epithelial cells in the mammary gland to secrete cytokines that recruit PMN to the site of infection where they can serve as phagocytes [28]. The lower SCC in cows fed OVE + SM compared with CON and OVE might indicate that Met supplementation enhances immunity. Further research is needed to determine more precisely the effects (and mechanisms) of Met in cows that are more susceptible to mastitis risk.

\section{Gene expression}

The mRNA expression of genes related to Met and glutathione metabolism, inflammation, and oxidative stress were evaluated to generate data on the possible mechanisms whereby Met elicits a response in PMN. The PMN function in dairy cows during the transition period is impaired in part due to high concentrations of NEFA and BHBA [32, 33]. Although in the present study NEFA and BHBA did not differ postpartum between treatments, the greater liver TAG accumulation in OVE than $\mathrm{CON}$ is indicative of a reduction in the capacity to export lipid out of the liver, also supported by the differences in blood VLDL concentration. Liver lipidosis clearly could impair cow performance. Research has demonstrated that increasing Met supply during the 


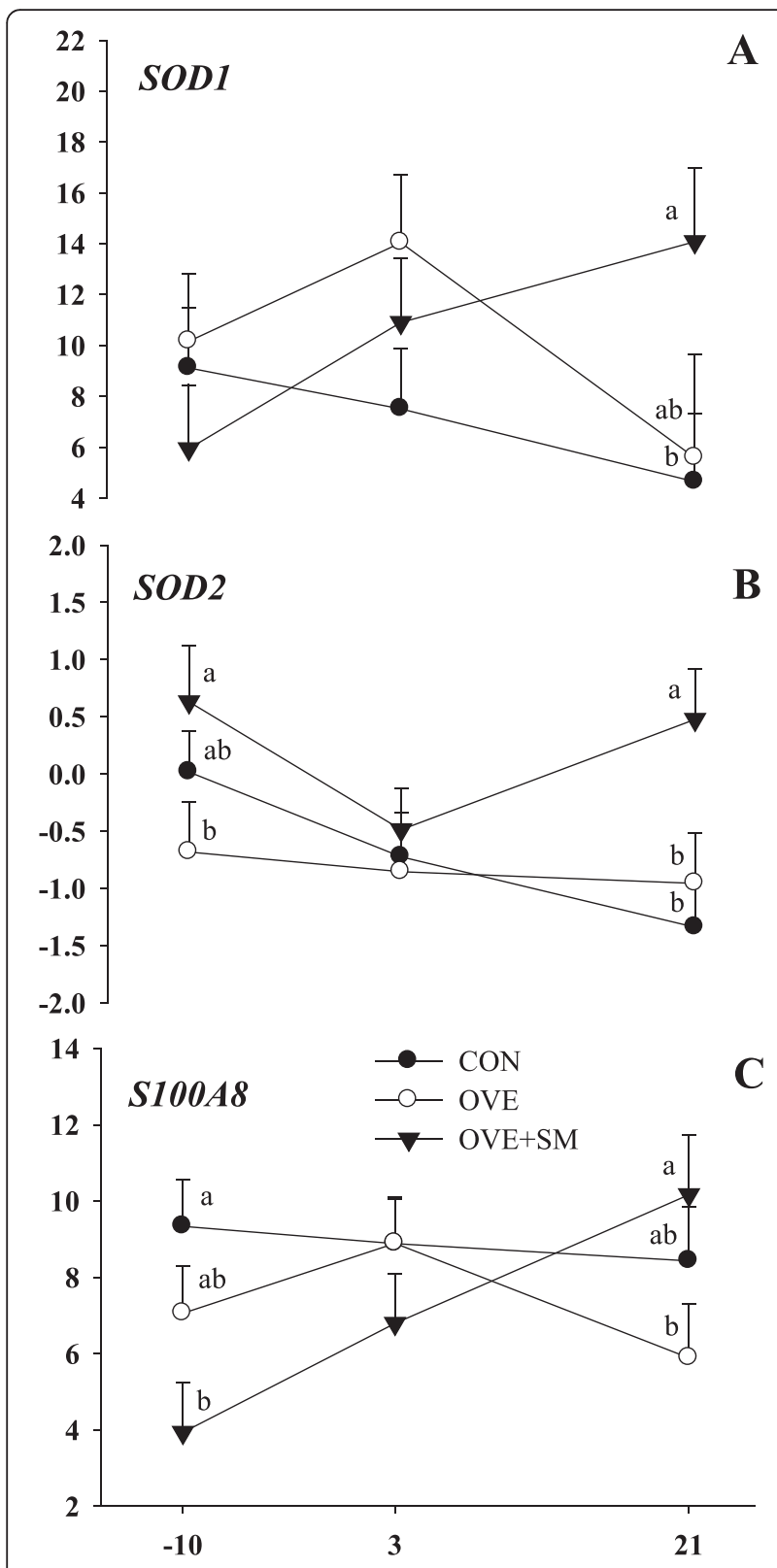

Day relative to parturition

Fig. 6 Expression of superoxide dismutase 1 (SOD1, panel a), superoxide dismutase 2 (SOD2, panel b), and S100 calcium binding protein A8 ( $5100 \mathrm{~A} 8$, panel c) in PMN of Holstein cows fed a lower-energycontrol diet (CON), higher-energy diet (OVE) or OVE plus Smartamine M (OVE + SM) during the close-up period and through the first $30 \mathrm{~d}$ postpartum. These genes related with oxidative stress and inflammation. ${ }^{\mathrm{a}-\mathrm{b}}$ Effect of diet $(P<0.10)$ at a specific time point

peripartal period increased hepatic expression of Met and glutathione metabolism-related genes, and decreased inflammation and oxidative stress [34]. However, to our knowledge, there are no published data reporting that Met supplementation has an effect on PMN from peripartal dairy cows.

\section{Methionine and glutathione metabolism}

The enzyme S-adenosyl-L-homocysteine hydrolase ( $A H C Y$ ) is involved in the pathway from Met to homocysteine which is a precursor of glutathione [35]. Protection against the damaging effects of free radicals is carried out by GSR (glutathione reductase) and GPX1 (glutathione peroxidase), among others, which are enzymes related with glutathione metabolism [36]. Although it is possible that the increase in Met supply reaching the liver could have a positive effect on flux through the GSR and GPX1 pathways, the fact that GSR and GPX1 did not differ indicates the existence of post-transcriptional control on both pathways.

\section{Inflammation}

The genes NFKB1 and TNF had the same pattern of response in OVE and OVE + SM cows. The greater NFKB1 expression could be partly associated with the numerical increase of STAT3 expression in those cows. It is wellestablished that the concentration of TNF- $\alpha$, which stimulates the pro-inflammatory response, can be affected by several factors, e.g. tissue damage, pathogen invasion, and excessive fat deposition [37, 38]. The similar mRNA expression of TNF in OVE and OVE + SM indicates that the positive effect of Met supplementation may not be strictly related with PMN function, and that other mechanisms are more directly linked with the greater DMI in OVE + SM compared with OVE. The down-regulation of RXRA is essential for PMN development from granulocyte or monocyte progenitors [39], supporting other data indicating that retinoic acid deficiency led to an increase in neutrophil numbers in mice [40]. Although we did not measure retinoic acid or vitamin A concentrations in plasma or isolated neutrophils, it could be possible that the observed changes in RXRA were associated with the availability of these metabolites. Thus, as previously demonstrated in mice [40], the markedly greater expression of RXRA in OVE + SM cows at $21 \mathrm{~d}$ might have been associated with the stimulation of neutrophil differentiation. Although we are unaware of research studying the interaction of retinoic acids and Met in immune cells, there is evidence that exogenous retinoic acids alters Met catabolism in liver, i.e. enhances $\mathrm{S}$-adenosylmethionie, $\mathrm{S}$-adenosylhomocysteine, and taurine concentrations [41]. Thus, the observed change in RXRA in response to Met might have elicited a positive effect on the concentration of circulating neutrophils and their ability to control oxidative stress and inflammation.

\section{Cellular receptors}

Neutrophils express a variety of adhesion molecules that are of fundamental importance in the acute inflammatory response by recognition of inflammatory sites, supporting adhesion, and transmigration across the endothelium as well as recognition and phagocytosis of 
opsonized microorganisms [42]. Among the four genes related with cellular receptors analyzed, SELL and ITGAM had a similar expression pattern in OVE + SM cows. Although homocysteine concentration was not measured, we speculate that feeding SM could have increased its concentration when compared with $\mathrm{CON}$ and OVE, and consequently, enhanced the ability for cell adhesion by the PMN as indicated by the greater SELL expression at d 21. Dudman et al. [30] reported that increasing homocysteine blood concentration from $\leq 10 \mu \mathrm{mol} / \mathrm{L}$ to $\geq 200 \mu \mathrm{mol} / \mathrm{L}$ increased neutrophil adhesion by $\sim 50 \%$.

\section{Oxidative stress}

Reactive oxygen metabolites (ROM) could serve as antimicrobial substances generated by the host defense mechanism to neutralize invading pathogens [43]. However, excessive production of ROM leads to loss of cell function, necrosis and apoptosis [44], and decreases dairy cow performance [45]. The imbalance between ROM production and the neutralizing capacity of antioxidant mechanisms is termed oxidative stress [46]. Antioxidant defenses are diverse and can be either synthesized in vivo or derived from the diet. The most efficient antioxidants are the enzymes SOD (SOD1, and SOD2), which can directly catalyze the reduction of ROM [47].

$\mathrm{Hu}$ et al. [48] reported that inhibition of SOD2 caused accumulation of ROM. Thus, the upregulation of $S O D$ isotypes in OVE + SM cows indicates that Met is linked to antioxidant mechanisms conferring protection against cell impairment from oxidative stress. Furthermore, several studies in non-ruminants have demonstrated direct protective effects of Met on oxidative stress [49-51] via the reaction of Met residues with ROM to form Met sulfoxide, hence, scavenging the reactive oxygen metabolites [49].

\section{Conclusions}

The similar pro-inflammatory response in both overfed groups of cows with and without supplemental Met suggests that the mechanisms associated with the positive benefits of feeding Smartamine M are not only associated with the biology of the PMN. The temporal adaptations in PMN of genes related with migration, development and cellular antioxidants indicate that Smartamine M supplementation was effective in alleviating negative effects of prepartal energy-overfeeding. Furthermore, the similar DMI and milk yield of those cows compared with cows fed the lower-energy diet underscore the idea that Met helps overcome the limitations of overfeeding energy during the prepartal period.

\section{Additional file}

Additional file 1: Table S1. Gene symbol, gene name, and description of the main biological function and biological process of the targets analyzed in PMN. Table S2. GeneBank accession number, hybridization position, sequence and amplicon size of primers used to analyze gene expression by qPCR. Table S3. Sequencing results of PCR products from primers of genes designed in this study. Table S4. Sequencing results of genes using BLASTN (http://www.ncbi.nlm.nih.gov) from NCBI against nucleotide collection ( $\mathrm{nr} / \mathrm{nt}$ ) with total score. Table S5. qPCR performance among the genes measured in PMN. (DOCX $40 \mathrm{~kb}$ )

\section{Competing interests}

The authors declare that they have no competing interests.

\section{Authors' contributions}

$\mathrm{CL}, \mathrm{FB}$, and $\mathrm{JO}$ performed the experiment, performed analyses, analyzed data, and drafted the manuscript. JJL, DL, and JKD conceived the experiment and proofread the manuscript. All authors participated in data interpretation. All authors approved the final version of the manuscript.

\section{Acknowledgements}

Financial support for the research was provided in part by Adisseo (Commentry, France) and Hatch funds under project ILLU-538-914, National Institute of Food and Agriculture, Washington, DC, USA. The authors thank Travis Michels and Mike Katterhenry of the University of Illinois Dairy Research Unit (Urbana) staff for help with animal management.

\section{Author details}

${ }^{1}$ Key Laboratory of Animal Genetics and Breeding of Ministry of Agriculture, National Engineering Laboratory of Animal Breeding, College of Animal Science and Technology, China Agricultural University, Beijing 100193, China. ${ }^{2}$ Department of Animal Sciences and Division of Nutritional Sciences, University of Illinois, Urbana, IL 61801, USA. ${ }^{3}$ Department of Animal and Rangeland Sciences, Oregon State University, Corvallis 97331OR, USA. ${ }^{4}$ Ruminant Technical Services, ADISSEO NA, Alpharetta 30022GA, USA

Received: 28 September 2015 Accepted: 29 February 2016

Published online: 09 March 2016

\section{References}

1. Soder KJ, Holden LA. Lymphocyte proliferation response of lactating dairy cows fed varying concentrations of rumen-protected methionine. J Dairy Sci. 1999:82:1935-42.

2. Chen $Y$, Yang $Y$, Miller ML, Shen D, Shertzer $H G$, Stringer KF, et al. Hepatocyte-specific Gclc deletion leads to rapid onset of steatosis with mitochondrial injury and liver failure. Hepatology. 2007;45:1118-28.

3. Osorio JS, Ji P, Drackley JK, Luchini D, Loor JJ. Supplemental Smartamine M or MetaSmart during the transition period benefits postpartal cow performance and blood neutrophil function. J Dairy Sci. 2013;96:6248-63.

4. Goff JP. Major advances in our understanding of nutritional influences on bovine health. J Dairy Sci. 2006;89:1292-301.

5. Sordillo LM, Contreras GA, Aitken SL. Metabolic factors affecting the inflammatory response of periparturient dairy cows. Anim Health Res Rev. 2009;10:53-63.

6. Moyes KM, Graugnard DE, Khan MJ, Mukesh M, Loor JJ. Postpartal immunometabolic gene network expression and function in blood neutrophils are altered in response to prepartal energy intake and postpartal intramammary inflammatory challenge. J Dairy Sci. 2014;97:2165-77.

7. Jain NC. In: Lee Y, Febiger S, editors. Schalm's Veterinary Hematology, 4th ed. Philadelphia: LeaFebiger; 1986. p. 676-730. Chapter 107.

8. Paape MJ, Bannerman DD, Zhao X, Lee JW. The bovine neutrophil: Structure and function in blood and milk. Vet Res. 2003;34:597-627.

9. Graugnard DE, Bionaz M, Trevisi E, Moyes KM, Salak-Johnson JL, Wallace RL, et al. Blood immunometabolic indices and polymorphonuclear neutrophil function in peripartum dairy cows are altered by level of dietary energy prepartum. J Dairy Sci. 2012;95:1749-58.

10. Graugnard DE, Moyes KM, Trevisi E, Khan MJ, Keisler D, Drackley JK, et al. Liver lipid content and inflammometabolic indices in peripartal dairy cows 
are altered in response to prepartal energy intake and postpartal intramammary inflammatory challenge. J Dairy Sci. 2013;96:918-35.

11. Dann HM, Litherland NB, Underwood JP, Bionaz M, D'Angelo A, McFadden JW, et al. Diets during far-off and close-up dry periods affect periparturient metabolism and lactation in multiparous cows. J Dairy Sci. 2006;89:3563-77.

12. Janovick NA, Boisclair YR, Drackley JK. Prepartum dietary energy intake affects metabolism and health during the periparturient period in primiparous and multiparous Holstein cows. J Dairy Sci. 2011;94:1385-400

13. Ji P, Osorio JS, Drackley JK, Loor JJ. Overfeeding a moderate energy diet prepartum does not impair bovine subcutaneous adipose tissue insulin signal transduction and induces marked changes in peripartal gene network expression. J Dairy Sci. 2012;95:4333-51.

14. Khan MJ, Jacometo CB, Graugnard DE, Corrêa MN, Schmitt E, Cardoso F, et al. Overfeeding dairy cattle during late-pregnancy alters hepatic PPARaregulated pathways including hepatokines: impact on metabolism and peripheral insulin sensitivity. Gene Regul Syst Biol. 2014;8:97-111.

15. Vasquez JA, Perfield KL, Green HB, Drackley JK. Effects of close-up dietary energy strategy and prepartal dietary monensin on production and metabolism in Holstein cows. J Dairy Sci. 2011;94 Suppl 1:690.

16. Hara A, Radin NS. Lipid extraction of tissue with a low toxicity solvent. Anal Biochem. 1978:90:420-6.

17. Fletcher MJ. A colorimetric method for estimating serum triglycerides. Clin Chim Acta. 1968:22:393-7.

18. Foster LB, Dunn RT. Stable reagents for determination of serum triglycerides by a colorimetric Hantzsch condensation method. Clin Chem. 1973;19:338-40.

19. Moyes KM, Drackley JK, Morin DE, Loor JJ. Greater expression of TLR2, TLR4, and IL6 due to negative energy balance is associated with lower expression of HLA-DRA and HLA-A in bovine blood neutrophils after intramammary mastitis challenge with Streptococcus uberis. Funct Integr Genomics. 2010; 10:53-61.

20. Garcia M, Elsasser TH, Biswas D, Moyes KM. The effect of citrus-derived oil on bovine blood neutrophil function and gene expression in vitro. J Dairy Sci. 2015;98:918-26.

21. Moyes KM, Drackley JK, Salak-Johnson JL, Morin DE, Hope JC, Loor JJ. Dietary-induced negative energy balance has minimal effects on innate immunity during a Streptococcus uberis mastitis challenge in dairy cows during midlactation. J Dairy Sci. 2009;92:4301-16.

22. Bobe G, Young JW, Beitz DC. Pathology, etiology, prevention and treatment of fatty liver in dairy cows. J Dairy Sci. 2008;87:3105-24.

23. Auboiron S, Durand D, Bauchart D, Robert JC, Chapman MJ. Lipoprotein metabolism in the preruminant calf: Effect of a high fat diet supplemented with I-methionine. J Dairy Sci. 1994;77:1870-81.

24. Auboiron S, Durand D, Robert JC, Chapman MJ, Bauchart D. Effects of dietary fat and I-methionine on the hepatic metabolism of very low density lipoproteins in the preruminant calf, Bos spp. Reprod Nutr Dev. 1995;35:167-78.

25. Zom RLG, van Baal J, Goselink RMA, Bakker JA, de Veth MJ, van Vuuren A. Effect of rumen-protected choline on performance, blood metabolites, and hepatic triacylglycerols of periparturient dairy cows. J Dairy Sci. 2011;94: 4016-27.

26. Yao Z, Vance DE. The active synthesis of phosphatidylcholine is required for very low density lipoprotein secretion from rat hepatocytes. J Biol Chem. 1988;263:2998-3004

27. Martinov MV, Vitvitsky VM, Banerjee R, Ataullakhanov FI. The logic of the hepatic methionine metabolic cycle. Biochim Biophys Acta. 1804;2010:89-96.

28. Zhou Z, Bu DP, Vailati-Riboni M, Khan MJ, Graugnard DE, Luo J, Cardoso FC, Loor JJ. Prepartal dietary energy level affects peripartal bovine blood neutrophil metabolic, antioxidant, and inflammatory gene expression. J. Dairy Sci. 2015;98(8):5492-505.

29. Grimble RF. Sulphur amino acids and the metabolic response to cytokines. Adv Exp Med Biol. 1994;359:41-9.

30. Dudman NPB, Temple SE, Guo XW, Fu W, Perry MA. Homocysteine enhances neutrophil-endothelial interactions in both cultured human cell and rats in vivo. Circ Res. 1999;84:409-16.

31. Grimble RF. The effects of sulfur amino acids intake on immune function in humans. J Nutr. 2006;136:1660S-5S.

32. Suriyasathaporn W, Daemen AJ, Noordhuizen-Stassen EN, Dieleman SJ, Nielen M, Schukken YH. Beta-hydroxybutyrate levels in peripheral blood and ketone bodies supplemented in culture media affect the in vitro chemotaxis of bovine leukocytes. Vet Immunol Immunopathol. 1999;8:177-86.
33. Scalia D, Lacetera N, Bernabucci U, Demeyer K, Duchateau L, Burvenich C. In vitro effects of nonesterified fatty acids on bovine neutrophils oxidative burst and viability. J Dairy Sci. 2006;89:147-54.

34. Osorio JS, Ji P, Drackley JK, Luchini D, Loor JJ. Smartamine M and MetaSmart supplementation during the peripartal period alter hepatic expression of gene networks in 1-carbon metabolism, inflammation, oxidative stress, and the growth hormone-insulin-like growth factor 1 axis pathways. J Dairy Sci. 2014; 97:7451-64.

35. Barić I. Inherited disorders in the conversion of methionine to homocysteine. J Inherit Metab Dis. 2009;32:459-71.

36. Mlakar SJ, Osredkar J, Prezelj J, Marc J. Antioxidant enzymes GSR, SOD1, SOD2, and CAT gene variants and bone mineral density values in postmenopausal women: a genetic association analysis. Menopause. 2012 19:368-76.

37. O'Boyle N, Corl CM, Gandy JC, Sordillo LM. Relationship of body condition score and oxidant stress to tumor necrosis factor expression in dairy cattle. Vet Immunol Immunopathol. 2006;113:297-304.

38. Loor JJ, Bertoni G, Hosseini A, Roche JR, Trevisi E. Functional welfare-using biochemical and molecular technologies to understand better the welfare state of peripartal dairy cattle. Anim Prod Sci. 2013;53:931-53.

39. Taschner S, Koesters C, Platzer B, Jorgl A, Ellmeier W, Benesch T. Dowregulation of RXRa expression is essential for neutrophil development from granulocyte/monocyte progenitors. Blood. 2007;109:971-9.

40. Kastner P, Chan S. Function of RARa during the maturation of neutrophils. Oncogene. 2001;20:7178-85.

41. Schalinske KL, Steele RD. 13-cis-retinoic acid alters methionine metabolism in rats. J Nutr. 1991;121:1714-9.

42. Simon SI, Cherapanov V, Nadra I, Waddell TK, Seo SM, Wang Q, et al. Signaling functions of L-selectin in neutrophils: alterations in the cytoskeleton and colocalization with CD18. J Immunol. 1999;163:2891-901.

43. Vatansever F, de Melo WC, Avci P, Vecchio D, Sadasivan M, Gupta A. Antimicrobial strategies centered around reactive oxygen species bactericidal antibiotics, photodynamic therapy, and beyond. FEMS Microbiol Rev. 2013;37:955-89.

44. Nordberg J, Arner ESJ. Reactive oxygen species, antioxidants, and the mammalian thioredoxin system. Free Radic Biol Med. 2001;31:1287-312.

45. Miller JK, Brzezinska-Slebodzinska E, Madsen FC. Oxidative stress, antioxidants, and animal function. J Dairy Sci. 1993;76:2812-23.

46. Sies H. Oxidative stress: Oxidants and antioxidants. San Diego: Academic; 1991.

47. Sordillo LM, Aitken SL. Impact of oxidative stress on the health and immune function of dairy cattle. Vet Immunol Immunopathol. 2009;128:104-9.

48. Hu Y, Rosen DG, Zhou Y, Feng L, Yang G, Liu J, et al. Mitochondrial manganese-superoxide dismutase expression in ovarian cancer. J Biol Chem. 2005:280:39485-92

49. Moskovitz J, Bar-Noy S, Williams WM, Requena J, Berlett BS, Stadtman ER. Methionine sulfoxide reductase (MsrA) is a regulator of antioxidant defense and lifespan in mammals. Proc Natl Acad Sci. 2001;98:12920-5.

50. Stadtman ER, Moskovitz J, Berlett BS, Levine RL. Cyclic oxidation and reduction of protein methionine residues is an important antioxidant mechanism. Mol Cell Biochem. 2002;234/235:3-9.

51. Luo $S$, Levine RL. Methionine in proteins defends against oxidative stress. FASEB J. 2009;23:464-72.

\section{Submit your next manuscript to BioMed Central and we will help you at every step:}

- We accept pre-submission inquiries

- Our selector tool helps you to find the most relevant journal

- We provide round the clock customer support

- Convenient online submission

- Thorough peer review

- Inclusion in PubMed and all major indexing services

- Maximum visibility for your research

Submit your manuscript at www.biomedcentral.com/submit 